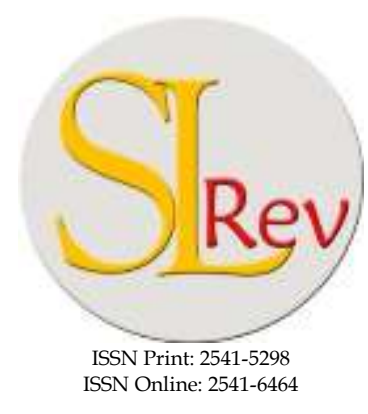

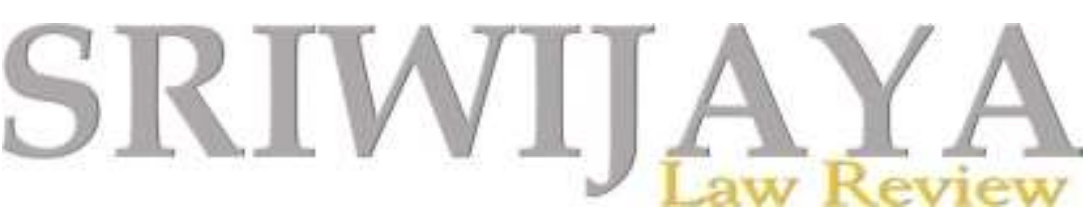

Editorial Office: Faculty of Law, Sriwijaya University, Jalan Srijaya Negara, Palembang, South Sumatra 30139, Indonesia. Phone: +62711-580063 Fax: +62711-581179

E-mail: sriwijayalawreview@unsri.ac.id| sriwijayalawreview@gmail.com Website: http://journal.fh.unsri.ac.id/index.php/sriwijayalawreview

\title{
The Urgency of Presidential Policy to Revitalize and Maintain the Existence of Cooperatives Based on Pancasila
}

\author{
Seno Wibowo Gumbira*, I Gusti Ayu Ketut Rachmi Handayani**, and Kukuh Tejomurti***
}

\begin{abstract}
The article aims to examines how the role of the President of the Republic of Indonesia as the head of state as well as the head of government through its policies and legal products. It is because the President has a role in creating a conducive atmosphere in the economic sector especially in revitalizing and maintaining the existence of a Cooperative as Indonesia's economic pillar based on Pancasila to face the wave of the liberal economy in the era of globalization. This situation occurs, perhaps, due to the lack of confidence and understanding of the Pancasila as a social philosophy. This problem can be observed by several phenomena occurring in the community such as the malignant and violent settlement of problems resolution in a social, political, cultural, legal, and religious system. This study applies normative methods with a statute approach. As a result, it can be concluded that a legal product comes from the 1945 Constitution to the Presidential legal products, namely government regulation and presidential instruction will have an implication to the objective and the result whether it is good or bad.
\end{abstract}

Keywords: National Economy; Pancasila; Presidential Policy.

\section{ARTICLE HISTORY:}

\section{DOI: 10.28946/slrev.Vol3.Iss2.289.pp199-224}

Received: May 13, 2019;

Reviewed: Jul 7, 2019;

Accepted: Jul 29, 2019;

Published: Jul 31, 2019.

$\begin{array}{ll}* & \text { Faculty of Law, Social and Political Science, } \\ \text { Universitas Terbuka. } & \text { Email: } \\ \text { seno@ecampus.ut.ac.id } \\ \text { Faculty of Law, Universitas Sebelas Maret. } \\ \text { Email: ayu_igk@staff.uns.ac.id } \\ \text { Faculty of Law, Universitas Sebelas Maret. } \\ \text { Email: kukuhmurtifhuns@staff.uns.ac.id }\end{array}$

\section{INTRODUCTION}

As the demands of the modern state, Indonesia must be based on the rule of law. This concept is to protect their people and entire native land, to improve the public welfare, to educate the people, and to achieve social justice. ${ }^{1}$ Those goals are embodied in Pancasila as a fundamental value of the state, especially in the second and fifth paragraphs of the Preamble of the 1945 Constitution of the Republic of Indonesia (hereinafter the 1945 Constitution). The second paragraph is mainly about just and humanity principle, and the fifth paragraph addresses social justice for the people, which reflects

1 I Gusti Ayu Ketut Rachmi Handayani, "Kedaulatan Sumber Daya Alam Di Indonesia Sebagai Aktualisasi Nilai-Nilai Pancasila," Jurnal Hukum Yustisia, Vol. 3 No. 1 January April 2014, pp51-52. 
Indonesia as a welfare state. Moreover, Pancasila also contains human rights guarantees, ${ }^{2}$ which embodied in the second paragraph of Pancasila. Therefore, the 1945 Constitution gives authority to the government to take action in fulfillment of those goals. Article 33 of the 1945 Constitution determines certain ways to achieve public welfare, which shall be carried out and becomes a guideline to constitute a policy.

However, it seems that the goals are challenging as addressed in the philosophy of the state and Indonesian people. Considering that Pancasila is the fundamental philosophy and the basis of the state formulated and hard-fought by the founding father, even though it has been ignored and marginalized by state practice which only shows and glorifies liberal principles and philosophy.

During the post-reformation era, Indonesia has experienced weak unity in a unitary state of Indonesia, since the reformation was carried out without a clear concept. The implication was on a condition of social anxiety, even have caused social chaos. As stated by a sociologist named Durkheim with his theory of "anomie" which addressed that in the event when society lost its consensus in which is the value of unity and common goals, then disorientation would occur inflicting people to be vulnerable of social chaos. $^{3}$ It is happening and being

2 Nurhidayatuloh, N., \& Febrian, F., 2019, "ASEAN and European Human Rights Mechanisms, What Should be Improved?" Padjadjaran Journal of Law, 6(1), pp151-167.

3 Ulber Silalahi, 2008, "Rekonsiliasi Sosial: Suatu Kerangka Analisis Dari Teori Konsensus," Jurnal Administrasi Publik, Vol. 5 No 22, p198. experienced by Indonesian people where the basis and values of togetherness within Pancasila have been buried and replaced with individual freedom. ${ }^{4}$

This situation occurs due to the lack of confidence and understanding of the Pancasila as a national philosophy. It can be observed by several phenomena of events that happen in the community, such as the malignant and violent settlement of problems resolution in social, political, cultural, legal, even religious issues. Based on that, Pancasila underlies and ensoul the state administration process in various fields and becomes a guideline for Indonesian in behaving and acting in their daily lives. Pancasila provides a clear direction and criteria regarding the feasibility or infeasibility of behavior and actions conducted by every Indonesian citizen in the life of society, nation and state $^{5}$. The most crucial part of value planting is the values of the Pancasila itself. Even though it was given as subject in school, there is no guarantee that the students fully understand it. Nowadays, most people only know the signs of Pancasila, but rarely apply the fundamental point of the values contained in the Pancasila Ideology. For example, students who have initial problems between individuals turn

Noer Effendi Tadjudin, "Situasi Sosial Masyarakat Kini dan Pancasila," Article in FGD Pancasila dan Penegakan Hukum, PSP UGM, 2015, p1.

5 Martitah, Reinforcement and Actualization of the Pancasila Ideology in the Life of the Nation, State, and Society. Focus Group Discussion Proceedings of the Indonesian People's Consultative Assembly Study Board and the Faculty of Law, the University of Diponegoro with the theme of Affirmation of Pancasila as the basis of the state, ideology of the nation in the 1945 Constitution of the Republic of Indonesia. Yogyakarta: Thafa Media, 2017, p92. 
out to be an inter-school problem, causing students to have a brawl. Even though they are taught the four precepts of Pancasila in one of it is prioritize consensus in resolving an issue ${ }^{6}$.

The nature and orientation of values such as materialism, individualism, hedonism, praxis, and pragmatic mindset have been spread in Indonesian society. The condition urges as a national problem because it refers to the fact that human rights are based on the doctrine of liberalism, which most certainly irrelevant with Indonesian declaration formulated in the Preamble of the 1945 Constitution. $^{7}$ The economic system of Indonesia is based

\footnotetext{
Martitah. Note 4. p92.

This idea is based on the explained argument in the first discussion on the formulation of Article 33 Amendments to the 1945 Constitution. There are some different opinions from economic experts. Mubyarto and Dawam Rahardjo were at odds with neoliberal economists. Liberals are summarized in literature Susanto Polamolo and Elnino M Husein Mohi. Debate to the Article 33 in the Amendment of the 1945 Constitution contains authentic copies of minutes of the Republic of Indonesia MPR Session 1999-2002. Firstly, an economic system based on the Pancasila ideology, namely a koperasi patterned with a profit-oriented corporation, are compared to the principle of family and mutual Koperasi as the previous act. Secondly, the three laws in the field of implementing economic activities are characterized by liberalism that is not following Article 33 of the 1945 Constitution of 1945 and Pancasila so that they contradict the spirit of Article 33 of the 1945 Constitution. Thus, the Constitutional Court of Indonesia cancels it. The Law No. 25 of 2007 concerning Investment, Law No. 22 of 2001 concerning Oil and Gas, Law No. 20 of 2001 concerning Electricity. Thirdly, it is added by the undeniable fact that there is much privatization of BUMN. Fourthly, the life of hedonism and individualism shows that Indonesia is a consumptive country https:// ekonomi.kompas.com/read/2018/09/06/1700570 26/perilaku-konsumtif-masyarakat-turutsebabkan-rupiah-anjlok [retrieved: $17^{\text {th }}$ Juli 2019].
}

on Pancasila, which concerns the application of family principle and cooperation. Hence, it becomes a national problem as it leads to the national identity crisis.

This phenomenon is inseparable from the influence of globalization, since the process of globalization, which has serious impacts on the existence of the nation and state of Indonesia. Many intellectuals or world scholars have predicted this. One of it is based on globalization as a result of the global economy concept, which raises to universality towards peoples' life starting from the smallest scope. The myth of globalization, which states that the world is finally wide open, lead to the changes in local culture and loss of identity and national identity. Many groups diversely interpret globalization in the present context. Globalization understanding is very close to modernization. In modern society, the current globalization is unstoppable and unable to be rejected. Exile or alienation of culture increasingly appears following the development of a global world. Symbols that appear in the manner of dressing, the way to communicate, language and way of thinking are shifts in cultural values that inevitably occur along with the advancement of modern society ideas ${ }^{8}$. Mansour Fakih mentioned that modernity as an idea of social change and over time has turned into an ideology 9 . The public trust that modernity will bring progress to civilization seems to result in cultural change. The

8 Emmanuel Raja Damaitu \& Ayuningtyas Saptarini, Moralitas Pancasila Dalam Kesesatan Globalisasi, Dalam Buku Pancasila Dalam Pusaran Globalisasi. Yogyakarta: LKIS, 2017, p281.

9 Emmanuel Raja Damaitu \& Ayuningtyas. Note 7, p281. 
culture of the community that used to respect local culture, with this current of globalization has mixed with the western culture which presents a form of uniformity with the emergence of global lifestyles such as food, clothing, and music ${ }^{10}$. The community which at first made simplicity as a value in life turned into an asocial and individualist society. Therefore, it is not an exaggeration to mention that the function and position of the Pancasila existence are beginning to be threatened in the reformation era, which after 18 years has not fully recovered and stable. The economic condition of citizens is maintained under the standard. The unemployment rate is still quite high. There is an undeniable fact that occurs in almost all countries in the world that the continuity and existence of the nation-state will be seriously challenged, unless the whole nation would pay attention to the matter, it will not rule out the possibility that the nation-state will collapse. Guido Bertucci and Adriana Alberti in their article titled "Globalization and the Role of the State: Challenges and Perspectives" states that globalization is a complex phenomenon, which encompasses a great variety of tendencies and trends in the economic, social and cultural spheres. It has a multidimensional character and thus does not lend itself to a unique definition. For purposes of simplicity, it may be explained as increasing and intensified flows between countries of goods, services, capital, ideas, information, and people, which produce cross border integration of economic numbers, social and cultural activities. National governments have played a positive role in providing greater interde-

10 Emmanuel Raja Damaitu \& Ayuningtyas. Note 7, p282. pendence and economic integration of specific activities through the elaboration and adoption of market-oriented policies and regulations, both the international and local levels ${ }^{11}$. Thus, it is not surprising that there is an agenda of integrating the economic system throughout the world by the free market mechanism, which is certainly known as the practice of a liberal economy. Besides that, James Petras and Henry Veltmer stated that globalization can be interpreted as a process of national and global markets liberalization and leads to the free flow of trade, capital, and information with a belief that this situation will create growth and human welfare ${ }^{12}$. Consciously or not, the promised welfare becomes an individual hegemony to participate in the big battles. Individuals are increasingly raised, and shared interests are increasingly marginalized. Therefore, the social welfare aspired in the philosophy of the Indonesian nation through Pancasila contained in the opening of the 1945 Constitution will only become a fantasy because economic resources and production are increasingly depleted and controlled as much as possible for the benefit of capital. This can be seen from the current condition; one of the indicators is the privatization of National Enterprises by foreign and private parties. The process of globalization which occurred quickly is a challenge and has a significant effect on

11 Guido Bertucci and Adriana Alberti Globalization and the Role of the State: Challenges and Perspectives. https://pdfs. semanticscholar.org/9edd/97224bb2978453e6ff 5c08afc56dd9e6064e.pdf anjlok [retrieved: July 8, 2019].

12 Paulus Rudolf Yuniarto, 2014, "Masalah Globalisasi di Indonesia: Antara Kepentingan dan Kebijakan dan Tantangan," Jurnal Kajian Wilayah, 5(1), p68. 
all peoples in various countries, including Indonesia itself. As stated by Anthony Giddens giving a term of "the runaway world" which according to him reflects as the process of changes in various fields, especially a social change in a country will be affected quickly and simply. ${ }^{13}$

In fact, even globalization has a latent function as a market expansion by developed countries. Therefore, globalization needs to be positioned as a product of the developed countries economic interests. In other words, in this context, it can be referred that science, technology, and rational human thought, are only aids in developing socialeconomic interests (the ideology of capitalism). As stated by Scholtre First, Globalization is internationalization, and based on this perspective; the global term is an adjective to describe cross-border relations between countries. Second, globalization is essentially liberalization. ${ }^{14}$ With regard to this matter, globalization is articulated as a process of removing govern restrictions world economy. Based on this understanding, globalization is an important paradigm to describe international economic integration. The foundation of this matter began since the enactment of a new global social formation marked by the worldwide promulgation of the free trade policy.

The discourse on a liberal-capitalist economic system with a focus on the "market mechanism" in the economy can not be separated from the paradigm of

13 Anthony Giddens, Beyond Left, and Rigth: Tarian "Ideologi Alternatif" di atas Pusara Sosialisme dan Kapitalisme, Translator: Imam Khoiri. Yogyakarta: IRCiSoD, 2003, p74.

14 J.A. Scholtre, Globalization: A Critical Introductions, Palgrave, 2000, p102. "market economy" along with the development of socialist and capitalist economics. In this case, the government can organize the economy to achieve the prosperity of the country. As known, that the market economy for some people is believed to be able to bring the economy more efficiently, taking into account the existing resources in the economy can be utilized more optimally and no planning or supervision is needed from any party. Submitting economic activities to the market, and an invisible hand that will later bring the economy towards balance, and in a position of balance, the existing resources in the marketplace are utilized more optimally. This capitalist economic system paradigm requires free markets to solve financial problems, from production, consumption to distribution.

Thus, the more massive process of dissemination and the influence of economic globalization of this capitalism along with the frail belief and understanding of Pancasila as the philosophy of the nation. Indeed, there is the potential for liberalization of the Indonesian economic system based on Pancasila. One of these things can be observed from several symptoms, such as:

First, when discussing the formulation of Article 33 Amendments to the 1945 Constitution, there are differences in views on the economic expert team in the discussion of Chapter formulations on the national economy and Social welfare, especially the provisions of Article 33 of the Fourth Amendment to the Constitution. The expert team lead by Mubyanto consists of Rahardjo, Sri Adiningsih, Sri Mulyati (secretary), Syahrir, Bambang Sudibyo, and Didik Rachbini. The view 
was seen at the 16th meeting of the Working Committee of the Indonesian People's Consultative Assembly Ad Hoc committee I on May 16, 2001. The slices of the concept made different opinions among the economic expert team, which since the beginning of the discussion had been divided into two camps: Yogyakarta and Jakarta. The Discussion contains essential material. The Yogyakarta stronghold through Mubyarto was in a strict line to maintain the basic political fundamentals of the Indonesian economy based on Article 33 of the original Constitution text. While the Jakarta stronghold demanded a change towards a market economy system; as exercised by the New Order era, although he seems substantially modified his argument. ${ }^{15}$ In the end, the formulation of Article 33, paragraph 1 to 3 of the 1945 Constitution was not changed. However, there were additional paragraphs in Article 33 became five verses and deleted the explanation of Article 33 of the 1945 Constitution and followed by the complicated process until the resignation of economist Mubyarto at that time.

According to this preceding explanation, it can be concluded that the influence of the principles of liberal economic system is powerful to change the Indonesian economic system from Pancasila economic system to capitalist liberal economic system with market economic system mechanism. The unchanged formulation of Article 33 of the 1945 Constitution, does it become the

15 Susanto Polamolo dan Elnino M Husein Mohi, Debate of Article 33 during Amandement Session of 1945 Constitution Loading Authentic Copy of Notes of Indonesia PCA Meeting 19992002, Yogyakarta: Total Media, 2019, p66. strength of idealist economists expert with their ideological principles (Pancasila) won the fight? The authors conclude that it will not necessarily be, since the explanation of the original script of the 1945 Constitution Article 33 which has been deleted, arises confusion whether the Indonesian economic system will implement the Pancasila economic system with the family principle or not? In connection with this question, it is necessary to pay attention to the matters raised by Kaelan which stated that the backbone of the national economy to realize people's welfare, the rules of the article have been controlled by liberal economic principles as contained in Article 33 paragraph (4). Article 33 regarding national economy and public welfare, this is an inconsistent and incoherent with the preamble of 1945 Constitution and the national ideology Pancasila, since paragraph (1), (2), (3) (which based the economy on unity and peaceful manner) although being covered up by paragraph (4) which in essence economic democracy and its application is applying liberal economic. Further, stated by Kaelan that economic democracy based on the principle of a free fight is in contrary and incoherent with the principle of togetherness and family. ${ }^{16}$

Secondly, the number of laws in the field of implementing economic activities characterized by liberalism that are not under Article 33 of the 1945 Constitution and Pancasila, therefore that it contradicts the spirit of Article 33 of the 1945 Constitution makes it canceled by the

16 Kaelan, Inkonsitensi dan Inkoherensi Dalam Undang-Undang Dasar Negara Republik Indonesia Tahun 1945 Hasil Amandemen (Kajian Filosofis dan Yuridis), Yogyakarta: Paradigma, 2016, p177. 
Indonesian Constitutional Court. As for several judicial review decisions of the Constitutional Court that withdrew and declared the regulation under Article 33 of the 1945 Constitution, such as Law No. 25 of 2007 concerning Investment, Law No. 22 of 2001 concerning Oil and Gas, Law No. 20 of 2001 concerning Electricity. In fact, besides those laws there are still many regulations relating to the implementation of the Indonesian economy that are liberal and contrary to Article 33 of the 1945 Constitution and Pancasila, such as Law No. 19 of 2003 concerning State Enterprises where there are no rules which contain provisions about people's prosperity, Law No. 19 of 2004 concerning Forestry, it turns out that the provisions contained only guarantee capitalists so that the use of forest assets is not for the people's prosperity but only enjoyed by the capitalists, the private sector by evicting indigenous peoples as in the case of registers 45 and 47 in Lampung. This is either directly or indirectly due to the enactment of economic democracy in the provisions of Article 33 paragraph (4) of the 1945 Constitution, therefore the rules contained in Article 33 paragraph (1), (2), (3) of the 1945 Constitution are not realized consistently and during the development process of improving people's welfare due to multiple interpretations, therefore it can implement and make policies with liberal styles which clearly contradict with the preamble of the 1945 Constitution and Pancasila.

Liberal influence also affected cooperative activities in Indonesia. It can be seen that the Cooperatives Act in Indonesia was also canceled by a judicial review of the Indonesian Constitutional
Court Number 28/PUUXI/2013 concerning the testing of Law Number 17 of 2012 concerning Cooperatives (hereinafter referred as the 2012 Cooperatives Law). Whereas a cooperative is one of the ideal supporting economic structures for the Indonesian people. This is a result of the abolition of Article 33 of the original 1945 Constitution manuscript which creates multiple interpretations which subsequently had an impact on the making of capitalist cooperatives law which makes the current economic activities by cooperatives became incoherent and inconsistent with the spirit of Pancasila and the family principle contained in certain paragraphs in Article 33 of the 1945 Constitution, this is seen as a matter of consideration (Ratio Decidendi) the Judicial Review of the Indonesian Constitutional Court as follows:

1) The spirit of the corporation continues to penetrate into the joints of the life of the country, including business partners that are in line with the cooperation of cooperatives. It has eliminated the principle of family and mutual cooperation, which is a characteristic of a cooperatives. According to the Constitutional Court, the 2012 Cooperatives Law is in contrary to the 1945 Constitution.

2) Several articles governing the norms of cooperatives legal entities, participation capital from outside members, the authority of supervisors and co-operative councils are considered to revoke the spirit of popular sovereignty, economic democracy, family principle, togetherness guaranteed by the constitution; 
3) The Constitutional Court assesses Article 1 number 1 of the Cooperatives Law, which states that cooperatives as legal entities do not contain substantive terms, referring to the definition of a typical corporate building. It is not in line with the cooperatives as referred to in Article 33 paragraph (1) of the 1945 Constitution, therefore the applicant's argument that the notion of a cooperatives contains individualism so that the applicant's argument has legal grounds;

4) Article 50 paragraph (1) letters a, paragraph (2), letters a and e and Article 56 paragraph (1) which give the supervisor the task of proposing management, accepting or rejecting new members to dismiss contradictory members with Article 5 paragraph (1) and Article 29 paragraph (2) which make democracy and equality the basic values of cooperatives activities. "The article is contrary to the principles of economic democracy,"

5) Article 68 and Article 69 which require that cooperatives members buy cooperatives capital certificates are norms that are not in accordance with cooperatives principles which are voluntary and open and contrary to Article 33 paragraph (1) of the 1945 Constitution. "This means that the cooperatives orientation has shifted towards joint ventures as the primary (material and financial) capital.

6) The management capital of cooperatives also comes from members, not from non-members (external parties). "Any are investors from outside, makes the profits will no longer belong to members; instead they will be owned by investors."

7) The Cooperatives Law Court prioritizes material and financial capital schemes that override social capital, which is the fundamental characteristic of cooperatives as a typical entity of economic actors based on the 1945 Constitution. Therefore, the philosophy of the new Cooperatives Law is not in accordance with the nature of the economic structure as a joint business and based on principles of the family contained in Article 33 paragraph (1) of the 1945 Constitution. "The definition of the cooperatives has been elaborated in other articles in the Cooperatives Law, thereby reducing or even negating the rights and obligations of members by making the supervisory authority too broad. As a result, according to the Court, cooperatives are the same and not different from limited liability companies. The cooperatives has lost its constitutional spirit as an entity of a typical nation of economic philosophies of mutual cooperation.

To avoid the legal vacuum, the Act No. 25 of 1992 concerning cooperatives (hereinafter referred to as the 1992 Cooperatives Law) were re-enacted. Model decisions that formulate new norms are based on a specific condition and are considered urgent to be implemented immediately. There is a problem of implementation if the decision of the Constitutional Court only states that a norm is contradictory and does not have binding power, then there will be a vacuum of norms while the rule is being, will, even 
be implemented but cause constitutional problems especially in its application. ${ }^{17}$ Certainly, this also raises the question of whether the Constitutional Court of the Republic of Indonesia has the authority to revive or enact a law that is declared invalid? Indeed, this is a problem in the enactment of the Act which has been declared invalid previously.

Establishment of Law No. 17 of 2012 concerning Cooperatives-patterned corporation and profit-oriented as a renewal of Law No. 25 of 1992 is also indirectly due to the abolition of the explanation of the original manuscript of Article 33 of the 1945 Constitution which makes it not available on the amendment to the 1945 Constitution, then the provisions of Article 33 in the constitution give rise to multiple interpretations. Whereas in the explanation of the original manuscript Article 33 of the 1945 Constitution states "In article 33 listed the basis of economic democracy, production is carried out by all, for all under the leadership or surveillance of members of the community. It is the prosperity of the community that is prioritized, not the prosperity of a person. Therefore the economy is structured as a joint venture based on family efforts. Build a company that is in accordance with it is a cooperatives. Furthermore, the economy is based on economic democracy, prosperity for all people. Therefore production branches that are important to the state and which control the lives of many people must be controlled by the state. If not, the production will fall into the hands of a

17 Nimatul Huda, Kekuatan Eksekutorial Putusan Mahakamah Konstitusi, Yogyakarta: UII Press, 2018, p178. powerful person and a lot of people who are oppressed. Only companies that do not control the livelihood of many people may be in the hands of someone. Then, earth, water, and the natural wealth contained in the earth are the main points of people's prosperity. Therefore it must be controlled by the state and used for the greatest prosperity of the people". Thus it can be concluded that the economic system based on the 1945 Constitution opens up great opportunities for the implementation of the economy in Indonesia with market mechanisms that are characterized by a liberal or neoliberal economic system that has penetrated into cooperatives forms which are expected to become Indonesia's economic pillars in achieving prosperity based on social justice contained in Pancasila and the 1945 Constitution as the initial concept in which the Indonesian state was formed.

As it is known in this case, the significant role of the executive institution plays a significant role in carrying out and forming policies, especially those related to the welfare of the people. Indeed, the President or the authority has a huge and central role, considering that the President is the highest leader in the executive body. Article 1 paragraph 2 of the 1945 Constitution indicates a giving affirmation of Article 4 paragraph 1 of the 1945 Constitution. The affirmation of the adoption of presidential government systems, by emphasizing the position of the President as head of state as well as head of government can not be separated and directly chosen by the people. Therefore the President has the sovereign executive to conduct the independent power and inherent power. President, as 
the head of government and administration, has a general duty and authority in its scope. This task and authority make it possible to become more widespread in line with the expansion of state or government duties and authorities, especially in carrying out their functions. Thus the commitment and role of the President are fundamental, such as a guide which creates a conducive climate in the economy especially in revitalizing and maintaining the existence of cooperatives based on the Pancasila as the economy's pillar based on Pancasila in facing the dissemination of liberal economic principles in the era of globalization.

Based on the foregoing matters, the formulation of the problem to be examined arises the question of whether and how the role of the President as head of state and head of government through policy and its legal products can create a conducive climate in the economic sector especially in revitalizing and maintaining the existence of cooperatives as economic pillar based on Pancasila in facing the dissemination of liberal economic principles in the era of globalization? Thus the thing to be examined is very relevant to the title of this article, " The Urgency of Presidential Policy to Revitalize, Maintain Existence of Cooperatives Based on Pancasila."

\section{RESEARCH METHODS}

This study uses normative methods in nature of explorative-analytical. The data used is secondary data in the form of primary legal materials and secondary legal materials. ${ }^{18}$ Conducting a scientific study must use a method. The method means finding information in an arranged and systematic manner. The steps carried out must be clear and strictly restricted to avoid too broad interpretation. Examining the existing problems, this study uses a doctrinal juridical approach as an approach to reviewing the law as a doctrine or normative set of rules. This approach is carried out through a literature review or legal research. In this case, the authors analyze the principles of law, legal norms, and opinions of scholars or legal experts.

The data used in this study are secondary data in the form of documents, books, scientific works and papers, journals, and miscellaneous. After the secondary data is collected, it is then analyzed qualitatively to analyze and answer the problem.

\section{ANALYSIS AND DISCUSSION The Urgency of Presidential Policy to Revitalize and Maintain The Existence of Cooperatives Based on Pancasila}

Prior to address the discussion regarding the urgency of Presidential policy to revitalize and maintain the existence of cooperatives as a pillar of economic based on Pancasila in facing the dissemination of liberal economic principles in the era of globalization, the authors will discuss the law first as a means or tool to carry out social engineering, by presenting the concept of "law as tool of social engineering", as stated by Rosco Pound. Pound describes that law is not only able to be used to perpetuate power, but the law

18 Soerjono Soekanto dan Sri Mamuji, Penelitian Hukum Normatif Suatu Tinjauan Singkat, Jakarta: Rajawali Pers, 2007, pp13-14. 
also considered as a social engineering tool (law as a tool of social engineering). ${ }^{19}$ After discussing the theory, the authors will then analyze its relevance to whether the Presidential Policy may revitalize and maintain the existence of the Cooperatives as an economic pillar in facing the dissemination of liberal economic principles in the globalization era or not? This method uses to expect the study to be presented systematically.

In Indonesia, the practice of government in the concept of law as a tool of social engineering was introduced by Mochtar Kusumaatmadja, which stated that the use of law as a means to manipulate society towards a government (executive) policy scenario was needed by developing countries, far exceeding the needs of advanced industrial countries already established, because developed countries already have a legal mechanism that has "a way" to accommodate changes in society, while developing countries do not. ${ }^{20}$ The opinion concludes that the use of legal mechanisms in developing countries is generally not as developed as in developing countries. Thus, the law is needed to manipulate behavior/attitude of the community. Therefore it is expected to support economic and social development, which expected to bring the Indonesian people's participation. In addition, the use of law as a tool of social engineering stated by Mochtar is also intended to the changes of community in an orderly manner.

19 Lily Rasjidi, Dasar-Dasar Filsafat Hukum, Bandung: Citra Adtya, 1990, p47.

20 Mochtar Kusuma Atmaja, dalam Soetandyo Wignjosoebroto, Dari Hukum Kolonial Ke Hukum Nasional: Dinamika Sosial Politik dan Perkembangan Hukum di Indonesia, Jakarta: Rajawali Pers, 1994, p231.
However, in Indonesia, the use of law as a means of social engineering for the welfare of a just and prosperous society has not yet seen significant. It is seen that there are many laws and regulations issued by the government in the context of socioeconomic development by basing themselves on the concept of law as a tool of social engineering, it turns out that socio-economic development is carried out by the government by using laws and regulations through its legal policy as a means to change the behavior of the people in the social and economic fields did not succeed in realizing the national goals, namely the creation of a just and prosperous society in this case, namely about cooperatives in Indonesia. It is very obvious that one of the legal facilities issued by the executive sector is causing the shift of economic activities based on the Pancasila, namely the Cooperatives.

It is obvious that the use of law as a tool of social engineering in the development of law has implications for the activities and conditions of economic activity. This is a comparison of the legal products of the President of the Suharto government and the reform era. In contrast to the New Order era, President Soeharto's administration through Presidential Instruction No. 4 of 1984 concerning the Development and Development of Village Unit cooperatives (VUC), making the cooperatives as an Indonesian economic pillar who based on Pancasila has contributed to the development and promotion of cooperatives as sokoguru national economy.

Considering that through Presidential Instruction No. 4 of 1984, the President as head of government ordered related 
ministries and agencies to involve VUC in every economic activity such as distributing fertilizers, necessities, and other services such as the right to pay electricity bills to pay property taxes and other activities, namely save borrow. Thus the role of cooperatives is very empowered and it can also be said that at the time the regulation came into force cooperatives contributed significantly to advancing the Indonesian economy. This had an impact because when the Inpres applied a cooperatives with such a role in obtaining the significant capital gained from its activities and with the capital, it was then used again for savings and loan activities in economic activities, especially farmers in Indonesia at that time. Besides that, in the new order, the development of Cooperatives performance during Pelita V was seen from a large number of VUC units and Non- VUC cooperatives and their members.

The development of the implementation of cooperatives development and institutional efforts in the fourth year of the Five-Year Development Plan (Repelita) V (Table 1) showed encouraging results. The number of cooperatives growing in the community and the number of cooperatives members is increasing. Likewise, the business sector of cooperatives is also increasingly diverse, and the number as well as variety of businesses are growing both in terms of quality and quantity.

The number of cooperatives in Repelita V (Table 1) also showed an increase. The number of cooperatives in the fourth year of Repelita $\mathrm{V}$ has reached 39,031 , consisting of 30,282 non-VUC cooperatives and 8,749 VUC. When compared with the number of existing subdistricts, which are 3,762 sub-districts, there is an average of 2-3 VUC in each sub-district and approximately eight nonVUC cooperatives in each sub-district. The spread of the number of cooperatives/VUC illustrates that cooperative services have been relatively and evenly distributed and are increasingly able to reach out to members and surrounding communities. This can be seen based on data from 1984 to 1989 which are as follows: ${ }^{21}$

Table 1: Development of Performance Cooperatives during Pelita V

\begin{tabular}{llllll}
\hline $\mathrm{N}$ & Descriptions & $\begin{array}{l}1966- \\
67\end{array}$ & $\begin{array}{l}1967- \\
68\end{array}$ & $\begin{array}{l}1968- \\
\mathrm{o}\end{array}$ & $\begin{array}{l}\text { GR } \\
(\%)\end{array}$ \\
\hline 1 & Total of VUC (unit) & 7.350 & 7.470 & 7.873 & 4.33 \\
\hline 2 & Total of Non-VUC & 23.096 & 23.692 & 25.45 & 6.28 \\
& (Unit) & & & 1 & \\
\hline 3 & Total member of VUC & 15.733. & 16.682. & 17.49 & 13.12 \\
& (Person) & 000 & 000 & 4.000 & \\
\hline 4 & Total member of Non- & 5.845 .0 & 8.863 .0 & 9.668. & 20.10 \\
& VUC (Person) & 00 & 00 & 000 & \\
\hline 5 & Total of saving (IDR & 414.995 & 435.745 & - & 44.64 \\
& Million) & .1 & & & \\
\hline 6 & Amount of business & 1.45295 & 2.218 .0 & 2.214. & 7.433 \\
& volume (IDR Million) & 5.4 & 00 & 000 & \\
\hline 7 & Total of the remaining & 39.445 & & - & 19.31 \\
& business & & & & \\
& (IDR Million) & & & & \\
\hline 8 & Capital & & & \\
& (IDR Million) & 870.446 & $1,183.8$ & - & \\
& *Source: Cooperative & & 07.6 & & \\
& Institution Coaching & & & & \\
\hline & & & & & \\
\hline
\end{tabular}

The number of cooperatives in Repelita V also shows an increase (Table 2). The number of cooperatives in the fourth year of Repelita V has reached 39,031, consisting of 30,282 non-VUC cooperatives and 8,749 VUC. When compared with the number of existing subdistricts, namely 3,762 sub-districts, there are an average of 2-3 VUC in each subdistrict and around 8 non-VUC cooperatives in each sub-district. The spread of the number of cooperatives / KUD illustrates that cooperative services have been fairly and evenly distributed and are increasingly able to reach out to members and surrounding communities.

21 Directorate General of Cooperative Institution Development. 
Whereas from 1988 to 1992 , they were as follows: 22

Table 2: Development of Performance Cooperatives during 1988-1992

\begin{tabular}{|c|c|c|c|c|c|c|}
\hline \multirow{2}{*}{$\begin{array}{l}\mathrm{N} \\
\mathrm{o}\end{array}$} & \multirow{2}{*}{$\begin{array}{l}\text { Descrip- } \\
\text { tion }\end{array}$} & \multirow[t]{2}{*}{1988} & \multicolumn{4}{|c|}{ Repelita V } \\
\hline & & & 1989 & 1990 & 1991 & 1992 \\
\hline 1 & NonVUC & 25.451 & 27.871 & 28.168 & 29.323 & 30.282 \\
\hline \multirow[t]{2}{*}{2} & VUC & 7.873 & 8.276 & 8.334 & 8.535 & 8.749 \\
\hline & Total & 33.324 & 36.147 & 36.502 & 37.858 & 39.031 \\
\hline 1) & $\begin{array}{l}\text { Cumulativ } \\
\text { Combined }\end{array}$ & $\begin{array}{l}\text { number } \\
\text { d Parent }\end{array}$ & e 1968 & ad includ & Primary & Central, \\
\hline 2) & Numbers a & repaired & & & & \\
\hline 3) & Temporary & umbers, u & Decem & r 1992 & & \\
\hline
\end{tabular}

The policies for fostering cooperative institutions in the fourth year of Repelita V include the following:

Table 3 show about terms of cultivation and development of human resources in cooperatives carried out policies by providing training of boards, managers, employees, and cadres of cooperatives continue to be carried out to improve the ability of human resources in the cooperative movement. Since 1990/1991 the number of educated cadres has continued to decrease, however, the quality of education has been improved. This is aimed at the cadres of educated cooperatives can disseminate the knowledge they have obtained to other cooperative cadres. Thus, the cooperative movement is more involved in disseminating the results of cooperative education. In the fourth year of Repelita V, the number of cooperative training participants reached 11,922 people, an increase of $14.9 \%$. The increase in cooperative training in the fourth year of the Repelita V was mainly due to the increasing number of managers, administrators and field practices who were trained to support the increase in the independence of cooperatives Based on this policy, VUC cooperatives at that time

22 Directorate General of Cooperative Institution Development. produced managers or human resources who had received significant cooperative training which had implications to increase cooperative capital and the creation of food self-sufficiency to make an increase in the level of welfare of the Indonesian people at that time. Table 3, the number of managers owned by cooperatives / VUC is described. In the fourth year of Repelita $\mathrm{V}$, the number of managers owned by non-VUC cooperatives was only $5.0 \%$ of the number of non-VUC cooperatives that existed that year. The number of managers owned by the VUC in the same year amounted to $52.5 \%$ of the total VUC in the year concerned. The low level of manager ownership by cooperatives / VUC is generally due to the manager's function is still held by the cooperative management. When compared with VUC, the percentage of manager ownership by non-VUC cooperatives is relatively lower. This illustrates that the use of managers in the management of non-VUC cooperative businesses should be improved. Furthermore, Table 3 it also appears that the development of the number of managers owned by VUC in the last five years has continued to decline. To help so that cooperatives / VUC can have managers who can manage and develop cooperative / VUC businesses, education for managers and business technical officers continues to be improved so that they truly can play a professional role as managers. In addition, for VUC in backward and remote areas, the shortage of managers is overcome by placing Educated Voluntary Workers (EVW) in VUC for 2 (two) years for co-management of cooperative businesses. This can be seen based on statistical data as follows: 
Table 3: The Success of VUC Human Resources Development and Non-VUC with Managers During 1988-1992

\begin{tabular}{llllll}
\hline Description & \multirow{5}{*}{1988} & \multicolumn{5}{c}{ Repelita V } \\
\cline { 3 - 6 } & & \multicolumn{5}{c}{1989} & 1990 & 1991 & 1992 \\
\hline Non VUC & & & & \\
Total Unit & 25.451 & 27.871 & 28.168 & 29.323 & 30.282 \\
Total Manager & 1.200 & 1.397 & 1.447 & 1.365 & 1.527 \\
Percentage & $4.7 \%$ & $5.0 \%$ & $5.1 \%$ & $4.7 \%$ & $5.0 \%$ \\
\hline VUC & & & & \\
Total Unit & 7.873 & 8.276 & 8.334 & 8.535 & 8.749 \\
Total Manager & 5.090 & 5.068 & 5.069 & 4.843 & 4.595 \\
Percentage & $64,7 \%$ & $61.2 \%$ & $60.8 \%$ & $56.7 \%$ & $52.5 \%$ \\
\hline 1) Cumulative numbers since 1968 \\
2) Temporary numbers until December 1992 \\
3) The number of managers of the year concerned divided by the
\end{tabular}

In terms of member savings, the capital and business value of cooperatives in the fourth year of Repelita V (Table 4) show an increase in the number of member deposits in the fourth year of Repeita V amounting to Rp 1,122.5 billion and business capital of Rp 3,155.3 billion. Thus, the number of member deposits is still $35.6 \%$ of business capital in the same year. This means that $64.4 \%$ of business capital comes from outside the cooperative. For this reason, efforts to raise capital, among others, through savings and loan activities, still need to be improved. In the new Cooperative Law, capital from outside the cooperative can be obtained from banks or other cooperatives, but can also be obtained from the issuance of bonds and other debt securities. In this case, achieving significant results in the fourth year of Repelita $\mathrm{V}$, the business value has reached $\mathrm{Rp}$ $6,810.0$ billion or $59.2 \%$ higher than the previous year. The increase in business value was mainly due to the increasing efforts of cooperatives/VUC, among others in the fields of food procurement, clove marketing, folk fisheries, small industries and folk handicrafts, transportation services and marketing of rural electricity services. This can be seen as follows:
Table 4: Members' savings, capital and value of cooperatives business for the period 1988 - 1992 (IDR Million)

\begin{tabular}{lllllc}
\hline Description & \multirow{2}{*}{1988} & \multicolumn{5}{c}{ Repelita V } \\
\cline { 3 - 6 } & & 1989 & 1990 & 1991 & 1992 \\
\hline $\begin{array}{l}\text { Amount of } \\
\text { saving }\end{array}$ & 518.0 & 518. & 638.0 & 706.0 & $1.122,5$ \\
\hline Amount of & 926.0 & 1.24 & 1.574. & 1.796 .0 & 3.155 .3 \\
capital & & 2.9 & 6 & & \\
\hline $\begin{array}{l}\text { Amount of } \\
\text { Business } \\
\text { Value }\end{array}$ & 2.031. & 3.28 & 3.543. & 4.278 .6 & 6.681 .0 \\
1. & 6 & 4.1 & 6 & 6 & \\
2. Annual Number & & & & \\
Temporary number until December 1992 & \\
Rapelita shows that to help small traders, co-
\end{tabular}
Rapelita shows that to help small traders, cooperatives / cooperatives also channel Candak Kulak Credit (CKC). The number of cooperatives that distributed CKC in the fourth year of Repelita V had not developed. In the fourth year of Repelita V, the number of customers served increased by $0.7 \%$ compared to the previous year and the credit turnover increased by $2.5 \%$ compared to the previous year. Regarding of this rather limited development of CKC, at the beginning of 1993 improvements were made in the CKC distribution mechanism, by increasing the role of banks in the supervision of CKC management.

Table 5 The table for the implementation of candak credit for 1988 - 1992

\begin{tabular}{|c|c|c|c|c|c|}
\hline \multirow[t]{2}{*}{ Description } & \multirow[t]{2}{*}{1988} & \multicolumn{4}{|c|}{ Repelita V } \\
\hline & & 1989 & 1990 & 1991 & 1992 \\
\hline $\begin{array}{l}\text { Total of Excetutant } \\
\text { cooperative } \\
\text { VUC/Non-VUC }\end{array}$ & $\begin{array}{l}5.98 \\
1\end{array}$ & 5.981 & 5.979 & 5.979 & 5.979 \\
\hline $\begin{array}{l}\text { Guarantie (IDR } \\
\text { Billion) }\end{array}$ & $\begin{array}{l}16.7 \\
93.4\end{array}$ & $\begin{array}{l}17.524 .8 \\
\end{array}$ & $\begin{array}{l}17.048 .4 \\
\end{array}$ & $\begin{array}{l}17.150, \\
8\end{array}$ & $\begin{array}{l}17.276 \\
.3\end{array}$ \\
\hline $\begin{array}{l}\text { Credit Value (IDR } \\
\text { Billion) }\end{array}$ & $\begin{array}{l}224 . \\
320 . \\
6\end{array}$ & 253.374 .8 & 256.259 .0 & $\begin{array}{l}263.80 \\
0.0\end{array}$ & $\begin{array}{l}270.62 \\
4.1\end{array}$ \\
\hline
\end{tabular}

Table 6 show terms of procurement and distribution of food, securing the basic price of grain/ rice at the farmer level, cooperatives/VUC is obliged to make purchases of grain/rice in accordance with the stipulated base price. The purchase price of grain/ rice was then sold to BULOG for national food stocks, and some were sold to the public market through the Center of 
VUC to secure the highest price of rice in the public market. Results of grain/rice procurement in Repelita $\mathrm{V}$ shows that the amount of grain/rice purchased in 1990/1991 and 1991/1992 appeared to be decreased compared to the previous year. It is due to the increase in gran/ rice production in 1990 by only $1 \%$ compared to the previous year due to the long dry season. However, in the fourth year of Repelita V, the development of food procurement has increased. In the fourth year of Repelita V, the number of VUC executant food procurement was 2,876 or an increase of $35.3 \%$ compared to the previous year. Total purchases for the year were 2.4 million tons, an increase of $72.7 \%$ compared to last year. It can be seen from the data as follows:

\section{Table 6: of Food Procurement Implementation (Grain/Rice) By VUC 1988/1989 - 1992/1993}

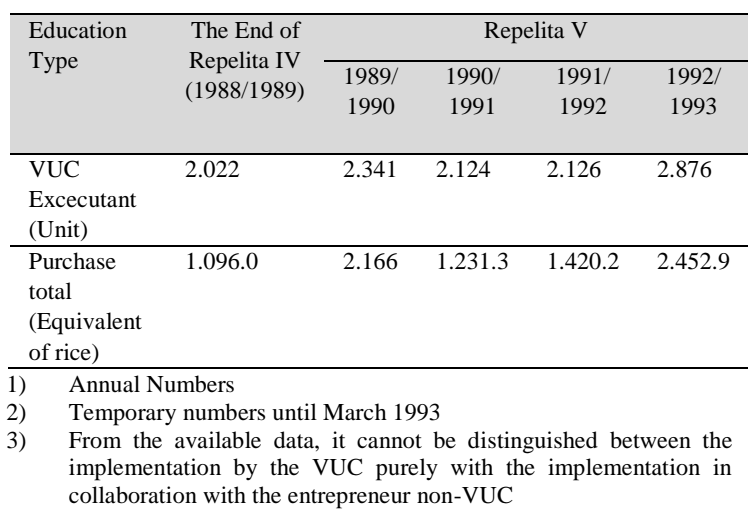

Based on the data from the National Development Planning Agency (Table 6), it can be seen that the President's commitment through the Presidential Instruction No. 4 of 1984 in the empowerment of cooperatives, especially village unit cooperatives has seemed to have considerable implications for the creation of food self-sufficiency and the welfare of cooperative members and the development of human resources in cooperatives, especially village unit cooperatives. The success of the VUC program to support RRI self-sufficiency in the 1970s and 1980s was mainly due to two main reasons, namely (1)VUC's strategies and work programs were focused on villages throughout the Republic of Indonesia; (2) cooperative programs are truly from the people, by the people, and for the people. In the future, such programs can be improved by cooperatives so that the program really benefits members and the community. While the support of regulations and legislation from the government is certainly important. ${ }^{23}$

The conditions and role of the cooperative after the fall of the new order government and the beginning of the reform era turned out to be changed. Precisely in 1998 the government was still in a state of monetary crisis and then issued a legal policy in the form of Presidential Instruction No. 18 of 1998 concerning Increasing Coaching and Development of Cooperatives (hereinafter referred to as Presidential Instruction No. 18 of 1998). In Presidential Instruction No. 18 of 1998 contained provision regarding :

1) Increase and encourage the spirit of self-reliance and participation in cooperating among the community accompanied by the rule of facilities in establishing cooperatives in accordance with the feasibility of the business and its economic interests;

2) Strengthen and empower cooperative institutions through increasing the quality and active participation of its

23 Nurdin Halid, Koperasi Pilar Negara, Membangun Karakter Bangsa Mewujudkan Negara Kesejahteraan dan Lestarinya Ekosistem NKRI, Jakarta: Jetpress bekerjasama dengan Dekopin, 2014, p185. 
members to enable act as a forum for healthy, resilient and independent people's economic strength;

3) Stabilize the expansion of the cooperative business base and increasing entrepreneurship and the professionalism of cooperative human resources in order to build the main business and pillar of the national economy rooted in society.

In addition, the Presidential Instruction No. 18 of 1998 also instructed relevant ministries at that time and the Governor of Bank Indonesia, Head of the Logistics Affairs Agency and the Governor of Level I Regional in accordance with their respective sectoral authority, both individually and jointly to :

1) Increase the role of cooperatives in all economic activities based on legislation concerning cooperatives;

2) Expand the share, and strengthening the role of cooperatives in national production and distribution activities to ensure the expansion and equal distribution of business opportunities;

3) Enhance the position of cooperatives in partnership with other economic enterprises to strengthen national economic competitiveness, equitable development, and enhance national unity.

With the issuance of Presidential Instruction No. 18 of 1998, the Presidential Instruction No. 4 of 1984 concerning the Coaching and Development of Village Unit Cooperatives was declared invalid and subsequently, the development of Village Unit Cooperatives was organized in the context of the Coaching and development of this Presidential
Instruction. Thus, through Presidential Instruction No. 18 of 1998, it has consequences to revoke the main role and function of VUC in its economic activities in the village, due to the community is given the widest opportunity to form cooperatives in accordance with business feasibility and economic interests. With such policies, it can potentially lead to competition between cooperatives both Non-VUC cooperatives and VUC even among other financial institutions, both domestic and foreign private. This condition certainly created free competition that was left to the market mechanism and this is a form of cooperatives liberalization in Indonesia.

The conditions for the establishment and enactment of Presidential Instruction No. 18 of 1998 brought positive and negative impacts both directly and indirectly to cooperatives in general and VUC in particular. On the positive effect with the opening of the freedom to create a cooperative by the community based on the aspirations and needs of the community in developing its business activities, it indeed causes the number of cooperative in Indonesia increased compared to the entry into force of Presidential Instruction No. 4 of 1984. Statistics record the number of the active cooperative by Province, from 2013 to 2016 totally is more than 148,220 units ${ }^{24}$.

With the significant number of cooperative after the enactment of Presidential Instruction No. 18 of 1998, there were indeed many cooperative that was established, but the number of cooperative also turned out not to have an impact on welfare distribution as the purpose of the regulation issuance. This

24 https://www.bps.go.id/statictable/2014/01/15/ 1314/jumlah-koperasi-aktif-menurut-provinsi2006-2016.html [retrieved: February 18, 2019]. 
condition was due to a large number of cooperative established were not followed by qualified guidance and supervision. Therefore they did not significantly produce and contribute to the development and creating prosperity concerning social justice. The most apparent thing was that since the end of 2014, the ministry has carried out a total cooperative reform, but the gross domestic product (GDP) of cooperative was still at the low point (4.1 percent). ${ }^{25}$ Even based on the current Indonesian national statistical agency, which has imported rice and fertilizers from other countries, meaning that the role of cooperative and village unit cooperative today to repeat food self-sufficiency was not as good as when it was implemented in Presidential Instruction No. 4 of 1984. The data derived from the national statistical body on the number of rice imports in 2017, showing 3.5 thousand tons. As of September 2018, there were 3.2 thousand tons. Indonesia has different condition when it had not imported rice at all in from 1985 until 1986. In that year, Indonesia even exported rice of 106 thousand tons in 1985 and 231 thousand tons in $1986 .{ }^{26}$.

In addition to these data, it can be seen based on empirical comparison sample of data, obtained from the Solo Pos (Table 7) Press that provided data on the conditions of VUC in Central Java, especially Klaten. In 1986, VUC successfully distributed Rp. $540,560,000$, - to 7,634 borrowers, whereas in 1987 VUC recorded rice sales to Bulog from 32 VUC of $24,484,700$ tons,

25 https://www.merdeka.com/uang/pembinaankurang-konsisten-kontribusi-koperasi-ke-pdb-rimasih-rendah.html [retrieved: February 18, 2019].

${ }^{26}$ Data from National Statistic Institution in the same year, 28 VUC sold 421,780 tons of rice to the public. In 1988, VUC bought 15,399,000 tons of rice. Some were sold to Bulog with $14,932,800$ tons by 31 VUC. The remaining 466,200 tons of rice were sold to the public by 27 VUC. In 1992, the distribution of candak kulak credit was decreased to Rp. 396,021,107 with a total of 10,147 borrowers, while rice sales to Bulog rose to $29,973,000$ tons and generally as much as 360,000 tons. ${ }^{27}$ Whereas in 2018, based on previous data, the sale and purchase and distribution of credit for Candak was not possible as, in the era of the 1990s, even half of them were not. Taking into account to the statistical data, it can be seen that the absence of regulation regarding the distribution of cooperative roles with other private parties with no rules added to the enactment of Presidential Instruction No. 18 of 1998 creates competition in the management and distribution of rice and fertilizer that caused Indonesia to import rice and fertilizer.

The current existence of VUC is also decreasing. Data in the Ministry of Cooperatives and Small, Medium Enterprises showed that out of 10,300 VUC units throughout the country, only 6,800 remain active. Not all of them are agricultural cooperatives. ${ }^{28}$ Cooperatives in the Merangin (Jambi) region was 288, 179 were active, 109 were inactive. ${ }^{29}$ While in Central Java, especially in the Klaten area,

27 Solo Pos Pers. Nasib KUD Kembang Kempis Tanpa Hak Istimewa. Edisi 6 December 2018, p1.

28 https://indonesiana.tempo.co/read/40831/2015/ 05/07/etha kereta/ke-mana-kud-saat-ini [retrieved: February 10, 2019].

29 http://jambi.tribunnews.com/2018/03/25/ada-2penyebab-109-koperasi-di-merangin-tak-aktif [retrieved: February 10, 2019]. 
it was recorded from 2015 to 2017 , as follows: ${ }^{30}$

Table 7: Data on the number Units and members of VUC in Klaten, Central Ja-

\begin{tabular}{lll}
\multicolumn{3}{c}{ va } \\
\hline Year & VUC Unit Total & Total of Members \\
\hline 2015 & 34 & 63.000 \\
\hline 2016 & 34 & 57.450 \\
\hline 2017 & 34 & 62.636 \\
\hline
\end{tabular}

Another problem arises is that there has been a lot of development in the aspect of cooperative such as the formation of Savings and Loans Cooperatives (SLC) with high interest loans as if moneylender under the guise of cooperatives and the many cooperatives that are easy to establish, causing widespread use of cooperative as a means of committing crime as an example of several cases as follows:

1) Savings and Loans Cooperative Tawakal Kaliwungu, Kendal, Central Java, allegedly escaped the money of its customers/cooperative members for Rp 2 billion. ${ }^{31}$

2) Cemara Buwana Banyubiru savings and loan cooperative was taken away by the owners and management of the cooperative; ${ }^{32}$

3) Arta Kusuma's Savings and Credit Cooperative (SLC) customer funds worth almost Rp 6 billion by the Founder. $^{33}$

30 Solo Pos Press. Nasib KUD Kembang Kempis Tanpa Hak Istimewa. Edisi 6 December 2018, p1.

31 https://daerah.sindonews.com/read/914777/22/ bos-koperasi-di-kendal-diduga-bawa-kaburuang-nasabah-rp2-m-1414130674 [retrieved: February 18, 2019].

32 https://regional.kompas.com/read/2017/06/20/ 19030041/deposito.dibawa.kabur.pengurus.kope rasi.nasabah.lapor.polisi [retrieved: February 18, 2019].

33 https://regional.kompas.com/read/2019/02/15/ 18044581/berkedok-koperasi-simpan-pinjam-
Problems in structural law are related to the existence of cooperatives in general and in particular, VUC not only in the number of units and the number of members but also related to human resources. The implementation of cooperative principles, and the administration and business systems are still less productive. As in the administrative system, cooperatives are mostly not well organized due to the quality of the cooperative's human resources that considered weak. Therefore, it is certainly necessary to improve the quality of human resources in cooperatives managers. In the aspect of regenerating cooperative human resources that are mostly old, there are no young people who want to work or pursue a cooperative because it is not promising. ${ }^{34}$ This is due to the limited capital of the cooperative which makes it difficult to improve the quality of human resources because the limitations of cooperatives in providing income to workers also affect the limitations in getting good quality human resources especially for recruiting qualified workers, because quality workers will tend to work for a finance company that is currently developing such as banking.

After the judicial review of the Indonesian Constitutional Court stating that the 2012 Cooperative Law contradicted the 1945 Constitution, therefore, it was no longer binding and did not have legal force, the Indonesian Constitutional Court to fill the legal vacuum imposed the 1992 Cooperative

wanita-ini-gelapkan-uang-nasabah [retrieved: February 18, 2019].

34 Solo Pos Pers. Nasib KUD Kembang Kempis Tanpa Hak Istimewa. Edisi 6 December 2018, p5. 
Act. Currently, the Cooperative Bill is still in a complicated process. This Cooperative Bill has been driven by two camps. First is the strong money lenders who are not willing to affirm the provision of strict sanctions for fake cooperatives that are widely circulating nowadays. The Indonesian Cooperative Council, which is actually a community organization desires it to be stipulated in the Bill as a single forum and requires the government to finance the organization from the state budget funds. If this continues to be forced, the existing law becomes imperative and also has the potential to contradict the Constitution, especially regarding freedom of gathered and union. ${ }^{35}$

Based on the foregoing description, it is known that a legal product policy can function as a social engineering tool (law as a tool of social engineering) influences the purpose of creating social conditions that are in accordance with the objectives of the legal policy or also has an impact on social life in the community which in this case is relevance that both the hierarchical level of the 1998 Cooperative Law structure and the 2012 Cooperative Law to form a regulation below between Inpres No. 4 of 1984 and Presidential Instruction No. 18 of 1998 both functioned as social engineering tools (law as a tool of social engineering) and certainly had implications for the existence and process of activities and the results of cooperatives in Indonesia. Thus, as stated by Abdul Manan, ${ }^{36}$ the economic globalization that

35 https://kabar24.bisnis.com/read/20190123/16/ 881789/pemerintah-didesak-terbitkan-perppuperkoperasian [retrieved: February 11, 2019]..

36 Abdul Manan, Peranan Hukum Dalam Pembangunan Ekonomi, Jakarta: Kencana, 2014, p45. is currently sweeping the world has an impact on the globalization of law, meaning that the established law/regulation must be able to anticipate economic activities. If the laws that are made cannot compensate the development of economic globalization, it will have an impact on the growth of capitalism with individual principles which contrary to the principle of togetherness and the principle of a family as mentioned in Article 33 of the 1945 Constitution.

With the condition of enacting the Cooperative Law in 1997 by the Indonesian Constitutional Court to tackle the legal vacuum, this is absolutely inappropriate and legally flawed. Because if it is examined in terms of theoretical Constitutional Court not as forming the Act (positivistic legislations) but as negative legislations. It is also related to the formal (immaterial) legal testing aspect which includes: ${ }^{37}$

1) Is the process of forming the regulations in accordance with the procedure or not?

2) What is the form or type of regulation to put the contents of the norm set right?

3) Is the agency that stipulates the regulation authorized?

4) Are the format, systematics, and other things in accordance with the standard guidelines or not?

If the regulations prove not to meet the formal requirements, then the whole regulation can be categorized as formally contrary to the procedure for establishing regulations. Moreover, this can be fatal as which the relevant laws and regulations

37 Jimly Asshiddiqie, Konstitusi Ekonomi Edisi cetakan Kedua, Jakarta: Kompas, 2016, p28. 
can be canceled or declared no longer binding in a whole. $^{38}$ Thus, a legal development strategy is necessary for accordance with the rule of law and places the law as commander.

The law as a social engineering tool (law as a tool of social engineering) will succeed if it is done wisely in order to give direction to rationally planned changes and must be formally formulated and certainly in harmony with the people's soul as stated by Savigny who states that the law is an expression of legal awareness of volksgesit and the soul of the people in this matter is Pancasila. Therefore, law through the concept of law as tool of social engineering has the purpose of forming and functioning the national legal system that originates from the nation's philosophy that is Pancasila and the 1945 Constitution which conducted by paying attention to the plurality of applicable legal procedures and continuous development carried out accompanied by guidance and complementary infrastructure and prepare legal rules in accordance with the personality of the Indonesian nation by placing law as commander in development.

To realize this, the development strategy of economic law in Indonesia needs to also pay attention to the concept of sustainable economic law development, which does not only carry out 'dismantling' the articles in a law or making new laws but also pay attention to and empower the carrying capacity of other aspects, such as: 1) legal education, 2) reforming the substance of the law, 3) the dispute resolution mechanism, which is authoritative and efficient; 4)

\footnotetext{
38 Jimly Asshiddiqie. Note 36. p28.
}

empowerment of business ethics, 5) fostering a nationalist spirit in legislative members; 6) commitment of the president and vice president, whose activities are carried out in a related way, together, and sustainably support each other. ${ }^{39}$

Development of economic law with a commitment from the President and his reliable and consistent representatives to make law as commander based on Pancasila, preamble and provisions and points in the 1945 Constitution was carried out due to the argument that the president's position as head of state and head of government. The president's position as head of state In the 1945 Constitution, the provisions concerning emergencies are regulated in two Articles, that are Article 12 and Article 22. Article 12 states, "The President declares a state of danger. The conditions and consequences of the danger are determined by law". Article 22 paragraph (1) states, "In the event of a compulsive matter, the President has the right to stipulate government regulations in lieu of the law." Based on these provisions of the 1945 Constitution, it can be seen that there are two categories of emergencies according to the 1945 Constitution, namely the state of danger and matters of compulsive force.

The parameter of emergency disclosed two theoretical and empirical views. According to the theory if it fulfills the elements: first, the threat element is dangerous (dangerous threat); second, the necessity element (reasonable necessity);

39 Adi Sulistyono, Pembangunan Hukum Ekonomi Untuk Mendukung Pencapaian Visi Indonesia 2030. Inaugural Speech for Professor of Economic Law at the Faculty of Law Universitas Sebelas Maret Surakarta on 17 November 2007, 2017, pp28-29. 
and third, the limited time available. ${ }^{40}$ If all three elements are fulfilled, based on Article 12 and the danger law, the President can declare a state of danger by taking actions not in accordance with the legal norms that apply under normal circumstances. Whereas in the perspective of empirical development, The Constitutional Court through Decision Number 138/PUU-VII/2009 concerning Testing of Substituting Government Regulations Law No. 4 of 2009 concerning Amendments to Law No. 30 of 2002 concerning the Corruption Eradication Commission, has provided an objective parameter for issuing a government regulation with an obstacle which forces the president to stipulate the government regulation which are as follows:

1) There is an urgent situation to resolve legal issues quickly based on the Law;

2) The required legislation has not stipulated therefore there is a legal vacuum or there are laws but are inadequate;

3) The legal vacuum cannot be overcome by making laws according to the usual procedure because it requires a long time while the urgent situation needs to be resolved immediately.

In addition, the President can assess whether the condition of the country is in a precarious and compelling state or there is a crisis that forces a government regulation to be adopted instead of a law (government regulation). Thus the declaration of danger according to Article 12 requires an objective assessment based on the law, while the application of Article 22 paragraph (1) is not based on an objective

40 Jimly Asshiddiqie, Hukum Tata Negara Darurat, Jakarta: Rajawali Press, 2007, p277. assessment based on the law, but subjectively the President can determine it personally. These provisions clearly constitute and become an enormous source of authority for the President. Thus this authority is also a factor that strengthens the position of the President in the presidential government system based on the 1945 Constitution. Therefore, the president as the head of government in carrying out executive duties and also as the head of administration has very broad scope of duties and authorities which make it possible to become more wide in line with the expansion of the tasks and authorities of the state or government, especially in carrying out its functions to prosper the people as stated in the opening of the 1945 Constitution ${ }^{41}$ and Pancasila.

As a form of commitment of the president and vice president in running the government by paying attention to the conditions of economic activity by the cooperative as the authors describe and to revitalize and maintain the existence of cooperatives as economic pillar based on Pancasila in facing the dissemination of liberal economic principles in the era of globalization, The government regulation is needed on revitalizing and maintaining the existence of cooperatives as a pillar of economic pillar based on Pancasila with provisions: First, stating that all provisions in the formulation of the 1998 Cooperative Law apply with reaffirmation that cooperatives are economic activities in accordance with the explanation of the

41 Rahayu Prasetyaningsih, 2017, “Menakar kekuasaan Presiden dalam Pembentukan Peraturan Perundang-Undangan Menurut Undang-Undang Dasar 1945," Jurnal Ilmu Hukum Padjadjaran. Vol. 4 No. 2. Bandung: Faculty of Law Universitas Padjadjaran, p269. 
original text of the 1945 Constitution "the economy is structured as a joint effort based on family principles" what is meant by the principle of family is cooperatives. It should be stated that the cooperative according to Mohammad Hatta is not merely an economic sector but is a social life that concerns values, spirit or spirit based on brotherhood, family, togetherness, mutual cooperation and so on, such as the spirit of the cooperative life. ${ }^{42}$ This is an affirmation that Article 33 of the 1945 Constitution is not multiple interpretations and accommodates Pancasila values such as the value of the third principle, the value of humanity that is just and civilized and the fifth principle of social justice for all Indonesian people. Thus there is direct and indirect confirmation that Indonesian cooperatives are carried out and conducted according to the principles of the Pancasila Economic System as stated by Mubyarto that the specific characteristics of the Pancasila economic system are First, the wheels of the economy are driven by economic, social, and moral. Second, the will of the entire community towards social equality (egalitarianism) in accordance with the principle of humanity. Third, the priority of economic policy is the creation of a national economy, which means nationalism animates every economic policy. Fourth, cooperatives are economic pillars and are the most concrete forms of joint ventures. Fifth, there is a clear and firm balance between planning at the national level and decentralization in the

42 Elli Ruslina, Dasar Perekonomian Indonesia Dalam Penyimpangan Mandat Konstitusi UUD Negara Tahun 1945, Yogyakarta: Total Media, 2013, p51. implementation of economic activities to ensure economic and social justice. ${ }^{43}$ It needs to be a concern for the birth of liberal legislation due to multiple interpretations of Article 33, which is due to the 1945 Constitution currently prescribed.

Second, besides the addition and affirmation of the explanation as foregoing stated in the government regulation, regulations also need to be formulated with the formulation of the prohibition on the formation of cooperatives operating in Indonesia funded by foreign countries with the inclusion of investments. This is aimed to prevent liberal economic practices in the form of cooperatives such as providing high interest in savings and loans by and to its members and enforcement or there is an affirmation of strict sanctions for fake cooperatives that are widely circulating, such as the form of cooperatives but accepting pawns or savings and loans whose interest exceeds BI's benchmark interest rate or the regulation of a savings and loan system that is more humane in accordance with the economic conditions of the cooperative region.

Third, revoking and declaring Presidential Instruction No. 18 of 1998 does not apply thus the consequence is the formation of cooperatives cannot be carried out immediately in accordance with the economic interests of individuals or corporations based on capitalists. The formation of $a$ cooperatives must be guided and approved by the cooperative ministry based on the Pancasila economic system.

43 Subiakto Tjakrawerdaja dkk., Sistem Ekonomi Pancasila, Jakarta: Rajawali Grafika Press, 2017, p73. 
Fourth, a single forum for guidance and education as well as human resource development in cooperatives is carried out by the Ministry of Cooperatives. It is aimed to prevent cooperatives used as a place of business that only prioritizes profit by certain groups of a non-governmental organization.

Fifth, the empowerment of cooperatives in the effort to achieve food self-sufficiency, such as opening, supporting and rearranging larger portions to cooperatives in distributing and purchasing grain and other materials related to achieving food self-sufficiency by involving all relevant institutions form derivative regulation which refers to the government regulation and the Presidential Instruction.

Sixth, the revitalization of
cooperatives
includes opening opportunities as large as large portions of economic activity to cooperatives in Indonesia such as distributing fertilizers, grain and food raw materials as sources of income for cooperatives, upgrading and education being carried out especially by relevant ministries such as the Ministry of Cooperatives and Small, Medium Enterprises and the Ministry of Research and Higher Education by conducting training and assignment of professional staff through their official duties in assisting management in cooperatives to create good and professional cooperative activities based on the Pancasila economic system. The education is intended to form a society and/or Indonesian nation that is Pancasila with a step for economists who study from abroad must adjust their economics to the ideology of the Pancasila. Therefore, the creation of equality and building The Pancasila paradigm is that it is a unified whole. There is an interdependent relationship between the various points of Pancasila that are mutually animated and imbued. The first point of discussion will also explain the next four points. So will the second, with the points in the discussion based on the first and third points and including the fourth, and fifth points. So on until the last point. Thus, the nature of human beings contained in the Pancasila will be discussed following this pattern. ${ }^{44}$

The government regulation which is a legal product as a form of commitment of the President of the Republic of Indonesia must be aligned with Pancasila, given that the ubi societas ibi ius means that there is a society, then there is a right law, because the law is a symptom in a pluralistic reality, which has many aspects, dimensions and facets. The law is rooted and formed in the process of interaction of various social aspects (political, economic, social, cultural, etc.) formed and helped shape society's order, its shape is determined by society with its various characteristics, which at the same time contributes to the form and characteristics of society itself. Therefore, the dynamics of the law are conditioned and condition society. ${ }^{45}$ In addition, according to Yudi Latif who stated: "The fundamental conception of the state and the ideals of each nation-state have their own

44 Zulkarim Salampesy, Iwan Triyuwono, Gugus Irianto dan Bambang Hariadi, "Pancasila Paradigm: Methodology of Wawasan Nusantara For Accounting Of Pancasila," Australian. Australasian Accounting, Business, and Finance Journal. Vol 12 Isu 1 Article 7, p104.

45 Benard Arief Shidarta, Refleksi Tentang Struktur Ilmu Hukum, Bandung: Mandar Maju, 2009, p166. 
characteristics arising from the historical setting, socio-cultural conditions, and the shared values and dreams of the nation concerned". 46 Therefore based on this description, there is a relationship between law and ideology, that is reciprocity. Law is not only an ideology supported by institutionalized social forces but also institutionalized social forces that are articulated in and reinforced by ideology, in other words, the ideology of determining legal products and the legal products will strengthen the prevailing ideology. ${ }^{47}$

\section{CONCLUSION}

Based on the foregoing elaboration in the discussion, it can be concluded that a legal product from the highest level of the hierarchy, from the constitution to the level of the Presidential policy through the government regulation and Presidential instruction will certainly have implications which have been in accordance with the objectives and expected to obtain proper results and vice versa. Thus, each legal product has function as well as a law as a tool of social engineering, as stated that Presidential Instruction Number 4 of 1984 succeeded in advancing cooperatives and at the same time played a role in the creation of food self-sufficiency, whereas Presidential Instruction Number 18 of 1998 initiated free competition which reflects a liberal system, thus liberal cooperatives which recently appears is not in

46 Yudi Latif, 2018, "The Religiosity, Nationality, And Sociality of Pancasila: Toward Pancasila Through Soekarno Ways," Studia Islamica Indonesian Journal For Islam Studies. Vol 25. Number 2. Jakarta: Studia Islamika, p209.

47 Petrus cCKL Bello, Ideologi Hukum Refleksi Filsafat Atas Ideologi di Balik Hukum, Bogor: Insan Merdeka, 2013, p34. accordance with the principle of togetherness and the principle of family based on Pancasila. Further, a legal product must be made rationally, formally formulated and is not in contrary with the value of Pancasila.

\section{REFERENCES \\ Books}

Asshiddiqie, Jimly. 2007. Hukum Tata Negara Darurat. Jakarta: Rajawali Press.

-------. 2016. Konstitusi Ekonomi Edisi etakan Kedua. Jakarta: Kompas.

Atmaja, Mochtar Kusuma, dalam Soetandyo Wignjosoebroto. 1994. Dari Hukum Kolonial Ke Hukum Nasional: Dinamika Sosial Politik dan Perkembangan Hukum di Indonesia. Jakarta: Rajawali Pers.

Bello, Petrus CKL. 2013. Ideologi Hukum Refleksi Filsafat Atas Ideologi Di Balik Hukum. Bogor: Insan Merdeka.

Damaitu, Emmanuel Raja dan Ayuningtyas Saptarini. 2017. Moralitas Pancasila Dalam Kesesatan Globalisasi. Pancasila Dalam Pusaran Globalisasi. Yogyakarta: LKIS.

Giddens, Anthony. 2003. Beyond Left and Rigth: Tarian "Ideologi Alternatif" di atas Pusara Sosialisme dan Kapitalisme. (Penerjemah: Imam Khoiri. Yogyakarta: IRCiSoD.

Halid, Nurdin. 2014. Cooperatives Pilar Negara, Membangun Karakter Bangsa Mewujudkan Negara Kesejahteraan dan Lestarinya Ekosistem NKRI. Jakarta: Jetpress bekerjasama dengan Dekopin.

Huda, Ni'matul. 2018. Kekuatan Eksekutorial Putusan Mahakamah Konstitusi. Yogyakarta: UII Press.

Kaelan. 2016. Inkonsitensi dan Inkoherensi Dalam Undang-Undang Dasar Negara Republik Indonesia Tahun 1945 Hasil 
Amandemen (Kajian Filosofis dan Yuridis). Yogyakarta: Paradigma.

Manan, Abdul. 2014. Peranan Hukum Dalam Pembangunan Ekonomi. Jakarta: Kencana.

Martitah. 2017. Reinforcement and Actualization of the Pancasila Ideology in the Life of the Nation, State, and Society. Focus Group Discussion Proceedings of the Indonesian People's Consultative Assembly Study Board and the Faculty of Law, the University of Diponegoro with the theme of Affirmation of Pancasila as the basis of the state, ideology of the nation in the 1945 Constitution of the Republic of Indonesia. Yogyakarta: Thafa Media.

Polamolo, Susanto dan Elnino M Husein Mohi. 2019. Perdebatan Pasal 33 Dalam Sidang Amandemen UUD 1945 Memuat Salinan Otentik Notulensi Sidang MPR RI 1999-2002. Yogyakarta: Total Media.

Rasjidi, Lily. 1990. Dasar-Dasar Filsafat Hukum. Bandung: Citra Adtya.

Ruslina, Elli. 2013. Dasar Perekonomian Indonesia Dalam Penyimpangan Mandat Konstitusi UUD Negara Tahun 1945. Yogyakarta: Total Media.

Sccholtre, J.A. 2000. Globalization: A Critical Introductions. Palgrave.

Shidarta, Benard Arief. 2009. Refleksi Tentang Struktur Ilmu Hukum. Bandung: Mandar Maju.

Soekanto, Soerjono dan Sri Mamuji. 2007. Penelitian Hukum Normatif Suatu Tinjauan Singkat. Jakarta: Rajawali Press.

Subiakto Tjakrawerdaja dkk. 2017. Sistem Ekonomi Pancasila. Jakarta. Rajawali Grafika Press.

\section{Journals and Articles}

Handayani, I Gusti Ayu Ketut Rachmi. 2014. "Kedaulatan Sumber Daya Alam Di Indonesia Sebagai Aktualisasi Nilai-Nilai Pancasila." Jurnal Hukum Yustisia. 3(1).
Latif, Yudi. 2018. "The Religiosity, Nationality, And Sociality of Pancasila: Toward Pancasila Through Soekarno Ways." Studia Islamica Indonesian Journal For Islam Studies. 25(2).

Nurhidayatuloh, N., \& Febrian, F. 2019. "ASEAN and European Human Rights Mechanisms, What Should be Improved?" Padjadjaran Journal of Law. 6(1).

Prasetyaningsih, Rahayu. 2017. "Menakar kekuasaan Presiden dalam Pembentukan Peraturan Perundang-Undangan Menurut Undang-Undang Dasar 1945." Jurnal Ilmu Hukum Padjadjaran. 4(2).

Salampesy, Zulkarim, Iwan Triyuwono, Gugus Irianto dan Bambang Hariadi. "Pancasila Paradigm: Methodology of Wawasan Nusantara For Acounting Of Pancasila." Australian. Australasian Accounting, Business and Finance Journal. 12(1).

Silalahi, Ulber. 2008. "Rekonsiliasi Sosial: Suatu Kerangka Analisis Dari Teori Konsensus." Jurnal Administrasi Publik. $5(22)$.

Sulistyono, Adi. 2017. "Pembangunan Hukum Ekonomi Untuk Mendukung Pencapaian Visi Indonesia 2030." Pidato Pengukuhan Guru Besar Hukum Ekonomi Pada Fakultas Hukum Universitas Sebelas Maret Surakarta Pada tanggal 17 Nopember 2007.

Tadjudin, Noer Effendi. 2015. "Situasi Sosial Masyarakat Kini dan Pancasila." Makalah Dalam FGD "Pancasila dan Penegakan Hukum, PSP UGM.

Yuniarto, Paulus Rudolf. 2014. "Masalah Globalisasi di Indonesia: Antara Kepentingan dan Kebijakan dan Tantangan.” Jurnal Kajian Wilayah. 5 (1).

\section{Press and Electronic Media}

Guido Bertucci and Adriana Alberti Globalization and the Role of the State: Chal- 
lenges and Perspectives https://pdfs.semanticscholar.org/9edd/972 24bb2978453e6ff5c08afc56dd9e6064e.pdf [retrieved: July 8, 2019].

https://www.bps.go.id/statictable/2014/01/ 15/1314/jumlah-cooperatives-aktifmenurut-provinsi-2006-2016.html [retrieved: February 18, 2019].

https://www.merdeka.com/uang/pembinaa n-kurang-konsisten-kontribusicooperatives-ke-pdb-ri-masih-rendah.html [retrieved: February 18, 2019].

https://indonesiana.tempo.co/read/40831/2 015/05/07/etha_kereta/ke-mana-kud-saatini [retrieved: February 10, 2019].

http://jambi.tribunnews.com/2018/03/25/a da-2-penyebab-109-cooperatives-dimerangin-tak-aktif accessed on 10 February 2018

https://daerah.sindonews.com/read/914777 /22/bos-cooperatives-di-kendal-didugabawa-kabur-uang-nasabah-rp2-m-

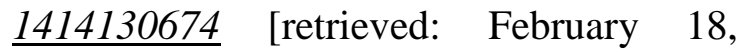
2019].

https://regional.kompas.com/read/2017/06/ 20/19030041/deposito.dibawa.kabur.pengu rus.cooperatives.nasabah.lapor.polisi [retrieved: February 18, 2019].

https://regional.kompas.com/read/2019/02/ 15/18044581/berkedok-cooperativessimpan-pinjam-wanita-ini-gelapkan-uangnasabah [retrieved: February 18, 2019]. https://kabar24.bisnis.com/read/20190123/ 16/881789/pemerintah-didesak-terbitkanperppu-percooperativesan [retrieved: February 11,2019$]$.

Media Cetak Solo Pos. Nasib KUD Kembang Kempis Tanpa Hak Istimewa. Edisi 6 December 2018.

Solo Pos Press. Nasib KUD Kembang Kempis Tanpa Hak Istimewa. Edisi 6 December 2018.

\section{Laws}

Presidential Instruction No. 4 of 1984 concerning the Development and Development of Village Unit Cooperatives (VUC).

Presidential Instruction No. 18 of 1998 concerning Increasing Coaching and Development of Cooperatives.

The 1945 Constitution of the Republic of Indonesia.

The Original Manuscript of the 1945 Constitution of Republic of Indonesia.

The Amendment of the 1945 Constitution of Republic of Indonesia.

The Law No. 17 of 2012 concerning Cooperatives.

The Law No. 25 of 1992 concerning Cooperatives. 